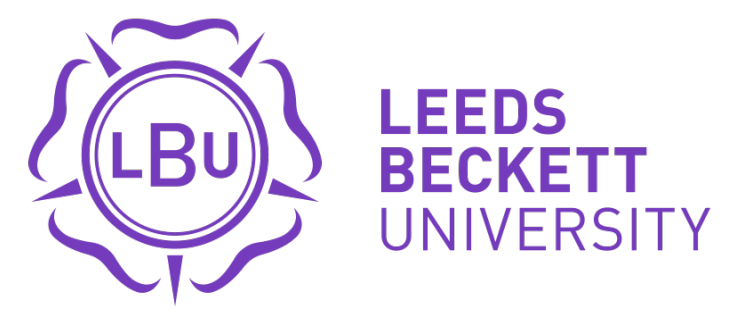

Citation:

Johnson, K (2018) Differences in appetite-related hormone concentrations between older and younger adults: A systematic review and meta-analysis. In: The Nutrition Society Summer Conference: Getting energy balance right, 10 July 2018 - 12 July 2018, Leeds. DOI: https://doi.org/10.1017/S0029665118001647

Link to Leeds Beckett Repository record:

https://eprints.leedsbeckett.ac.uk/id/eprint/6299/

Document Version:

Conference or Workshop Item (Published Version)

Creative Commons: Attribution-Noncommercial-No Derivative Works 4.0

The aim of the Leeds Beckett Repository is to provide open access to our research, as required by funder policies and permitted by publishers and copyright law.

The Leeds Beckett repository holds a wide range of publications, each of which has been checked for copyright and the relevant embargo period has been applied by the Research Services team.

We operate on a standard take-down policy. If you are the author or publisher of an output and you would like it removed from the repository, please contact us and we will investigate on a case-by-case basis.

Each thesis in the repository has been cleared where necessary by the author for third party copyright. If you would like a thesis to be removed from the repository or believe there is an issue with copyright, please contact us on openaccess@leedsbeckett.ac.uk and we will investigate on a case-by-case basis. 


\title{
Differences in appetite-related hormone concentrations between older and younger adults: A systematic review and meta-analysis
}

\author{
K.O. Johnson ${ }^{1}$, O.M. Shannon ${ }^{1,2}$, J. Matu ${ }^{3}$, A. Holliday ${ }^{1}$, T. Ispoglou ${ }^{1}$ and K. Deighton ${ }^{1}$ \\ ${ }^{1}$ Institue for Sport, Physical Activity, and Leisure, Leeds Beckett University, Leeds, LS6 3QS, UK, ${ }^{2}$ Human Nutrition \\ Research Centre, Institute of Cellular Medicine, Newcastle University, Newcastle Upon Tyne, NE2 4HH, UK and \\ ${ }^{3}$ Faculty of Medicine and Health, Leeds University, Leeds, LS2 9JT, UK
}

Unintentional weight loss is common in older adults, partly due to a loss of appetite termed 'the anorexia of ageing ${ }^{\text {(1) }}$. This is associated with adverse health outcomes including reduced functional capacity and increased mortality rates ${ }^{(2)}$, which emphasises the need for further understanding of this topic. Appetite-related hormones play an integral role in appetite regulation and energy balance but it remains unclear whether the circulating levels of these hormones differ between older and younger adults. Understanding these effects may help to identify potential mechanistic targets for future interventions to reduce age-related anorexia. Consequently, this systematic review and meta-analysis assessed differences in the circulating concentrations of appetite-related hormones between older and younger adults from previously published studies that compared these outcomes at rest in either the fasted or postprandial state.

PubMed and The Cochrane Library, as well as MEDLINE, SPORTDiscus and PsycINFO via EBSCOhost, were searched up to $12^{\text {th }}$ December 2017 for published original studies, conference proceedings, abstracts, dissertations and theses, which included the measurement of circulating appetite-related hormone concentrations in older and younger adults. Studies were included if they measured concentrations of appetite-related hormones in the fasted and/or postprandial state. Data were pooled using random-effects meta-analysis for fasted and postprandial concentrations of leptin, total ghrelin, glucagon-like-peptide 1, cholecystokinin and peptide YY, as well as postprandial concentrations of acylated ghrelin. Data are presented as the standardised mean difference (Hedges' g) with $95 \%$ confidence intervals.

Forty-one studies were included in the analysis, involving 843 younger adults and 832 older adults. Fasted cholecystokinin concentrations were significantly higher in older adults than younger adults (ES: $0.417,95 \%$ CI: 0.225 to $0.609 ; \mathrm{p}<0.001, n=14$ ). Fasted insulin concentrations were also significantly higher in older adults than younger adults (ES: $0.227,95 \% \mathrm{CI}: 0.036$ to $0.418 ; \mathrm{p}=0.020$, $n=21)$. There was a trend towards higher fasted leptin concentrations in older adults than younger adults (ES: $0.816,95 \%$ CI: -0.005 to $1.637 \mathrm{p}=0.051, n=11)$. Compared with younger adults, older adults displayed higher postprandial concentrations of leptin (ES: 0.554, $95 \%$ CI: 0.226 to $0.882 ; \mathrm{p}<0.001, n=9$ ), insulin (ES: $0.253,95 \% \mathrm{CI}: 0.102$ to $0.405 ; \mathrm{p}=0.001, n=26)$ and cholecystokinin (ES: $0.487,95 \%$ CI: 0.289 to $0.685 ; \mathrm{p}<0.001, n=16$ ). There was a trend towards higher postprandial glucagon-like-peptide 1 concentrations in older adults than younger adults (ES: $0.305,95 \% \mathrm{CI}:-0.013$ to $0.623, \mathrm{p}=0.060, n=11$ ). Fasted concentrations of total ghrelin, glucagon-like-peptide 1 and peptide YY did not differ significantly between older and younger adults (all p $>0.856$ ). Postprandial concentrations of total ghrelin, acylated ghrelin and peptide YY did not differ significantly between older and younger adults (all $\mathrm{p}>0.466)$.

Compared with younger adults, older adults displayed significantly higher circulating concentrations of the anorectic hormones cholecystokinin, leptin and insulin, which may contribute to the anorexia of ageing. However, other appetite-related hormones do not appear to differ consistently between older and younger adults. Interventions to reduce circulating levels of cholecystokinin, leptin and insulin may be beneficial for increasing appetite in older adults.

1. Morley JE \& Silver AJ (1988) Neurobiol aging 9, 9-16.

2. Wallace JI \& Schwartz RS (2002) Int J Cardiol 85, 15-21 